\title{
Catalytic Hydrogenation of Acetone to Isopropanol: An Environmentally Benign Approach
}

\author{
Ateeq Rahman \\ College of Engineering, Department of Chemical Engineering King Saud University, Post \\ Box-800, Riyadh-11421, Kingdom of Saudi Arabia
}

Received: 16th June 2010; Revised: 18th October 2010; Accepted: 25th October 2010

\begin{abstract}
The catalytic hydrogenation of acetone is an important area of catalytic process to produce fine chemicals. Hydrogenation of acetone has important applications for heat pumps, fuel cells or in fulfilling the sizeable demand for the production of 2-propanol. Catalytic vapour phase hydrogenation of acetone has gained attention over the decades with variety of homogeneous catalysts notably Iridium, $\mathrm{Rh}, \mathrm{Ru}$ complexes and heterogeneous catalysts comprising of Raney Nickel, Raney Sponge, $\mathrm{Ni} / \mathrm{Al}_{2} \mathrm{O}_{3}, \mathrm{Ni} / \mathrm{SiO}_{2}$, or $\mathrm{Co}-\mathrm{Al}_{2} \mathrm{O}_{3}, \mathrm{Pd}, \mathrm{Rh}$, $\mathrm{Ru}$, Re, or $\mathrm{Fe} / \mathrm{Al}_{2} \mathrm{O}_{3}$ supported on $\mathrm{SiO}_{2}$ or $\mathrm{MgO}$ ) and even $\mathrm{CoMgAl}$, NiMg Al layered double hydroxide, $\mathrm{Cu}$ metal, $\mathrm{CuO}, \mathrm{Cu}_{2} \mathrm{O}$. Nano catalysts are developed for actone reduction $\mathrm{Ni}$ maleate, cobalt oxide prepared in organic solvents. Author present a review on acetone hydrogenation under different conditions with various homogeneous and heterogeneous catalysts studied so far in literature and new strategies to develop economic and environmentally benign approach. (C) 2010 BCREC UNDIP. All rights reserved
\end{abstract}

Keywords: Hydrogenation, IPA, heterogeneous catalysts, acetone, HT-hydrotalcite catalysts.

Catalysis is likely to become a key element in the conversion of liquid or gaseous fuel cell. It's commonly referred to as fuel processing, often involves either hydrocarbons like methane, ethane, propane/LPG or liquid higher hydrocarbons or alcohols, e.g.: methanol, ethanol, however in principal any hydrocarbon containing such as dimethyl ether, ammonia are used. It's even possible to convert other fuels than hydrogen directly or indirectly in the fuel cells. Methanol, methane and carbon monoxide [1]. Catalytic science is a diverse field and evolving subject. Hydrogenation of acetone to isopropanol is regarded as a major chemical product in industry and academics since it has wide applications in heat pumps and fuel cell's for hydrogen storage.

\footnotetext{
* Corresponding Author.
}

E-mail address: ateeqr786@yahoo.com (A. Rahman) Phone: +966-4674631; Fax No: +966-4678770.
Isopropanol is widely regarded as essential commodity in fine chemical synthesis which is used as a solvent in industry and academia. Isopropanol is a major commodity which is projected to grow at a global rate of 1 to 3 percent per year. The reduction of ketones to the corresponding alcohols is very valuable in organic synthesis [2].

The state of the art of reduction of carbonyl compound namely acetone dates back decades when simple metals and hydrides were used for the reduction of ketones. Ex: acetone to 2-propanol [35]. Despite the history of the industrial application of acetone hydrogenation catalysts, opportunities remain for further improvements in hydrogenation rates, selectivity, stability, and applicability in hydrogenation of a wider range of materials. 
Increased fundamental understanding of hydrogenation catalysts would allow for rationallydirected improvements [6-9]. Vast number of homogeneous complexes and heterogeneous catalysts have been developed till date for the production of simple molecules in the area of fine chemical synthesis Fig 7. Published research papers seeking greater knowledge of acetone hydrogenation catalysts and this review here investigates one or more of 9 basic issues: (i) The variables important to catalyst synthesis and their effect on catalyst properties, particularly the catalyst's hydrogenation activity; (ii) The reaction between the supported and doped catalyst's components; (iii) The compositional and structural nature of the active catalyst species; and (iv) The postulated mechanism of catalytic hydrogenation; (v) Effect of solvent on hydrogenation of acetone; (vi) Effect of hydrogen pressure (vii) Effect of moisture concentration; (ix) Effect of temperature (viii) Effect of catalysts loading (ix) Kinetic modeling and Surface synergisms studies of $\mathrm{Cu}$, $\mathrm{CuO}$, and $\mathrm{Cu}_{2} \mathrm{O}$. Our examination of the literature in this review is organized according to these 9 basic categories.

Acetone to isopropanol a pie diagram is shown below about the percentage of articles in Elsevier publications in last 20 years with Journal of Catalysis showing $41 \%$ of publications and least being Applied catalysis. Statistics data represents there are about 6663 publications, and with nanocatalysts there are about 332 articles, from 1990 to 2010 found in Elsevier Publication given in table 1.

\section{Related Chemical Reaction}

The commercial production of MIBK involves a three step process [10]:

1. Acetone is first converted to diacetone alcohol (DAA) by aldol condensation of acetone.

2. Dehydration of DAA to mesityl oxide.

3. Selective hydrogenation of mesityl oxide to (MIBK) methyl isobutyl ketone is prepared by

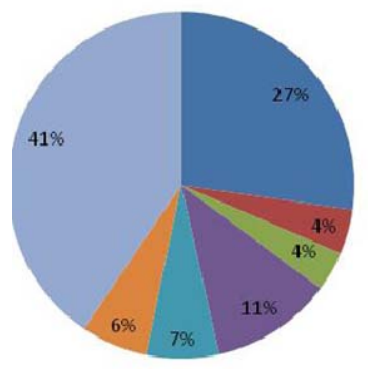

- Applied Catalysis A

- Applied Catalysis B

applied Catalysis

- Journal of molecular catalysis A n Joumal of molecular catalysis B w Journal of molecular catalysis wn Journal of catalysis

Figure 1: Pie diagram of literature for acetone reduction available in Elsevier hydrogenation of acetone and condensation with isopropanol in a single step.

Catalytic conversion of acetone to MIBK is reported in single step with several Pd catalysts. $90 \%$ selectivity to MIBK is reported in temperature range of $353 \mathrm{~K}$ to $433 \mathrm{~K}$ with overall conversion of $40 \%$.

Integrated process for making phenol involves alkylation of benzene with propene to obtain cumene, oxidation of cumene to cumene hydroperoxide, acid cleavage of cumene hydroperoxide to produce phenol and acetone, hydrogenation of acetone and dehydration of isopropanol in order to obtain propene that is subsequently fed to the first step of alkylation of benzene with propene [11].

\section{Metal doped ion-exchange resin}

Metal doped ion exchange resin were used for reduction of acetone to MIBK high conversions are obtained with deactivation of the catalysts and formation of water as byproduct which is a reversible reaction [12]. Metal being doped on bifunctional polymer resin for reduction of acetone with high conversion in low reaction rates, pseudo

Table 1: Represents acetone reduction publications in Elsevier journals

\begin{tabular}{|l|c|}
\hline \multicolumn{1}{|c|}{ Year } & No of publications \\
\hline 1990 and earlier & 2055 \\
1991 & 131 \\
1992 & 136 \\
1993 & 125 \\
1994 & 133 \\
1995 & 151 \\
1996 & 163 \\
1997 & 190 \\
1999 & 167 \\
2000 & 162 \\
2001 & 188 \\
2002 & 230 \\
2003 & 221 \\
2004 & 268 \\
2005 & 263 \\
2006 & 297 \\
2007 & 352 \\
2008 & 391 \\
2009 & 424 \\
2010 & 459 \\
\hline
\end{tabular}


equilibrium caused by reversible deactivation of the catalyst resulting in the formation of water insitu. Simultaneous removal of water during the course of the reaction which resulted in enhanced conversion [13].

\section{Catalysts used in hydrogenation of acetone to Isopropanol}

Wide range of homogeneous and heterogeneous catalysts are used for hydrogenation of acetone to isopropanol [14].

\subsection{Homogeneous catalysts}

Acetone hydrogenation with $\operatorname{Ir}(\mathrm{COD}) \mathrm{Cl}_{2}$ catalysts conversions $100 \%$, selectively $95 \%$ while remaining $5 \%$ being disopropyl ether. Iridium nanoclusters, plus $\left.\mathrm{HCl},[\{1,5-\mathrm{COD}\}]-\mathrm{IrCl}_{2}\right]_{2}$ under $\mathrm{H}_{2}$ [15]. $\mathrm{Rh}, \mathrm{Ir}(\mathrm{COD}) \mathrm{Cl}_{2}$ nano catalysts is active for hydrogenation of acetone to isopropanol but iridium (COD) $\mathrm{Cl}_{2}$ with ionic liquids is inactive catalysts leading to catalyst poisoning. Ozkar et. al., [16] carried out series of reactions with bulk metal, $\operatorname{Ir}(\mathrm{COD}) \mathrm{Cl}_{2}$ complex catalysts, and $\mathrm{Ir}(\mathrm{COD}) \mathrm{Cl}_{2}$ catalysts with ionic liquid which showed less activity [17-20]. The activity of catalysts $[\mathrm{Rh} \text { (norbornadiene) } \mathrm{Cl}]_{2}$ and phosphines or phosphonic acid esters is determined by the electronic and steric effects of the ligand. The

Figure 2: A schematic representation of acetone process and related products

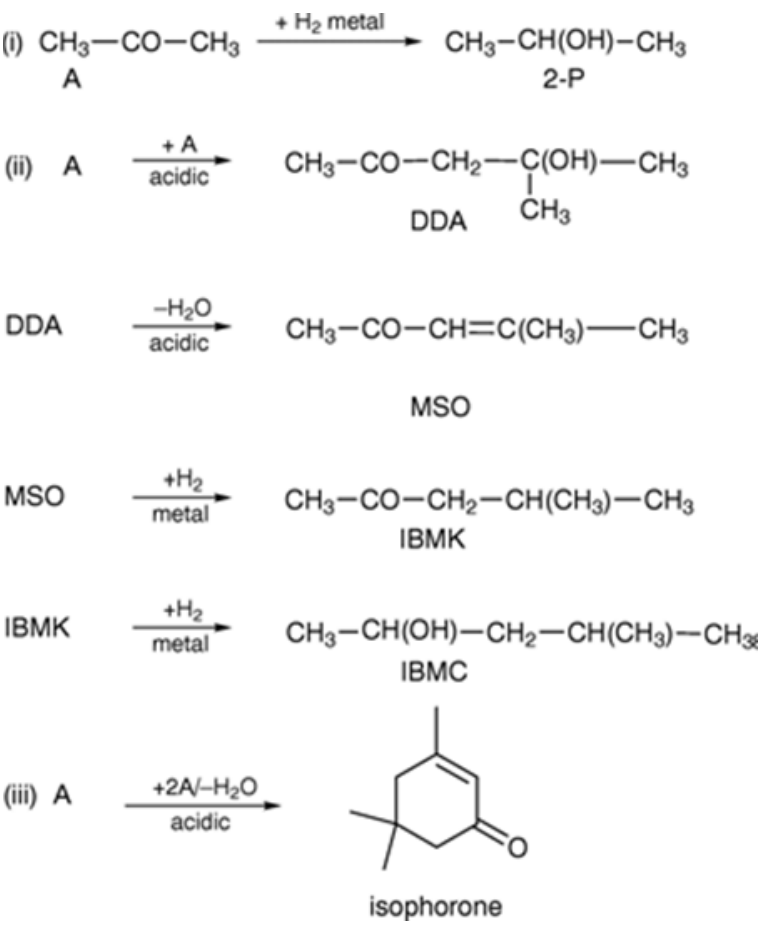

electronic parameter used was infrared vco value of $\mathrm{Rh}(\mathrm{PR} 3)_{2}(\mathrm{CO}) \mathrm{Cl}$ complexes containing same $\mathrm{P}$ (III)-ligands [21]. Phosphines with larger, or branched, alkyl groups show still lower vco values but yield's catalysts of lower, or even zero, activity because of the steric effects of the bulky ligands. Complex like tris(pentafluorophenyl)borane are used for the reduction of acetone to isopropanol with good conversion and selectivity. Homogeneous catalysts are well known for their major drawback i.e., recovery, reusability, workup difficulties, and reproducibility in a reliable manner [21].

\subsection{Heterogeneous catalysts}

Suitable wide range of heterogeneous catalysts have been developed for hydrogenation of acetone, temperatures in the range of $100-300^{\circ} \mathrm{C}$. Hydrogenation of acetone to isopropanol with raney nickel $\mathrm{Pd}, \mathrm{Pt}, \mathrm{Ru}, \mathrm{Rh}$ and various nickel catalysts.

\section{Supported catalysts: (Alumina \& silica, carbon, ceria supported $\mathrm{Rh}$ catalysts)}

Narayanan et.al [22] reported acetone hydrogenation with $\mathrm{Ni} / \mathrm{Al}_{2} \mathrm{O}_{3}$ conversions upto $40 \%$ conversion and selectivity only $3 \%$. Cr is used as promoter at elevated temperatures, pressures with sponge metal catalysts. In the company of $40 \%$ and $50 \% \quad \mathrm{NiAl}_{2} \mathrm{O}_{3}$ showed good conversions and selectivity. Whereas for $\mathrm{NiO}$ conversion and selectivity were less reported [23]. Conv 8-15\% $\mathrm{Ni} / \mathrm{SiO}_{2}$, conv $0-50 \% \mathrm{Ni} / \mathrm{Al}_{2} \mathrm{O}_{3}$, Pt/zeolite, $\mathrm{Pt} / \mathrm{SiO}_{2}$, conv $10-50 \% \mathrm{Ni}$ or $\mathrm{Co}$ or $\mathrm{Fe} / \mathrm{Al}_{2} \mathrm{O}_{3}$, Tc or Tc-M (M = $\mathrm{Pt}, \mathrm{Pd}, \mathrm{Rh}, \mathrm{Ru}, \mathrm{Ni}, \mathrm{Re}, \mathrm{Cr}, \mathrm{Co}) / \mathrm{Al}_{2} \mathrm{O}_{3}$, or supported on $\mathrm{SiO}_{2}$ or $\mathrm{MgO}$ ), Ni/6-zeolite (or zeolite-Y) ${ }_{3}$ and $\mathrm{ZnO}$ supported $\mathrm{Ni}$ and $\mathrm{Co}$ catalysts [24]. $\mathrm{pH}$ variation is also maintained at 7.0-8.2 with Raney nickel catalysts at high temperature and presssure with $99.3 \%$ conversion and $100 \%$ selectivity. $(\mathrm{Ni} / \mathrm{Al})$, copper based catalysts, copper-chromium, nickel, platinum, palladium, ruthenium, rhodium group catalysts are used for the reduction of acetone to IPA in liquid phase process. Ru, Raney nickel with molybdenum being adsorbed and raney nickel alone is inactive catalysts. Ketones reduction generally relies upon Raney nickel catalysts [25-26]. Nevertheless this catalyst entails rigid conditions at elevated temperatures and high pressure i.e. harsh reaction conditions are employed for effective performance. Pt supported activated carbon were used for reduction of acetone Pt catalyst were active from instu conducted FTIR, TPR, TPD [27]. The hydrogenation step of acetone is conducted in a single tube reactor using Raney 
nickel in presence of considerable amounts of water. Furthermore, still 0.2 wt \% of acetone remains in the reaction product. Use of Raney nickel in combination with high amounts of water have resulted in difficulty for working up the reaction product in azeotrope. Raney nickel doped Mo resulted in $95 \%$ conversion and $99 \%$ selectivity. Raney nickel conv $99.8 \%, 30 \% \mathrm{Ni}_{2} \mathrm{O}_{3}$ conv $72 \%$, and selectively $100 \%$, A 400 Raney Nickel sponge Cr promoted, Cr 2.5\% conv 99.9\% [28-29]. Acetone reduction with Raney nickel doped and undoped with $\mathrm{Co}, \mathrm{Cr}, \mathrm{Cu}, \mathrm{Mo}$, and $\mathrm{Ti}$ reactions were conducted in pressure with reference electrode [30]. $\mathrm{Ni} / \mathrm{Al}_{2} \mathrm{O}_{3}$ catalysts have been prepared by the co-precipitation method, for acetone hydrogenation at atmospheric pressure in temperature's between $373-473 \mathrm{~K}$. It is likely to synthesize selectively methyl isobutyl ketone (MIBK) or 2-propanol by varying experimental conditions. $>95 \%$ selectivity is achieved towards MIBK with 10 wt $\% \mathrm{Ni} / \mathrm{Al}_{2} \mathrm{O}_{3}$ catalyst at $373 \mathrm{~K}$ and at 1 atmosphere [31]. In liquid phase hydrogenation process with sponge or Raney nickel catalysts containing chromium as a promoter, greater catalyst productivity or activity is achieved. Under high mass transfer conditions, the reaction can be conducted at low pressure, e.g., 100 to 2000 psig (791 to $13,891 \mathrm{kPa}$ ), preferably from 150 to 1500 psig (1136 to $10,444 \mathrm{kPa})$, at moderate temperatures, e.g., 60 to $200^{\circ} \mathrm{C}$, preferably 80 to $160^{\circ} \mathrm{C}$, to achieve excellent rate and conversion [32]. Ceria supported Rh catalysts for the reduction of acetone by Cunningham et. al [33].

Complete loss of activity of the catalysts is observed when it's reduced and used for catalytic

Table 2 : List of Raney Nickel catalayst used for acetone to Isopropanol process. Ref 29

\begin{tabular}{clllc}
\hline Run & \multicolumn{1}{c}{ Catalyst } & Promoter & Min & $\begin{array}{c}\text { Conver- } \\
\text { sion }\end{array}$ \\
\hline A & $\begin{array}{l}\text { A400 Sponge } \\
\text { Nickel }\end{array}$ & $2.5 \% \mathrm{Cr}$ & 22 & $99.9 \%$ \\
B & Raney Cobalt 2724 & $2.15 \% \mathrm{Cr}$ & 28 & $99.9 \%$ \\
C & $\begin{array}{l}\text { A7000 Sponge } \\
\text { Nickel }\end{array}$ & $2 \% \mathrm{Mo}$ & 35 & $99.93 \%$ \\
D & $\begin{array}{l}\text { A5000 Sponge } \\
\text { Nickel }\end{array}$ & None & 45 & $99.92 \%$ \\
E & Raney Nickel 3300 & 1.1\% Mo & 46 & $99.94 \%$ \\
F & Raney Nickel 4200 & None & 62 & $99.92 \%$ \\
\hline
\end{tabular}

applications then catalysts is re-oxidized in $\mathrm{O}_{2}$ and reduced insitu which confirms $\mathrm{Rh}-\mathrm{H}$ species are formed from SMSI studies. Additional information on rhodium-induced modifications of surface and bulk properties of $\mathrm{Rh} / \mathrm{CeO}_{2}$ samples exposed to vacuum, $\mathrm{H}_{2}$ or $\mathrm{O}_{2}$ at various temperatures emerges from comparative measurements of $\mathrm{Rh} / \mathrm{CeO}_{2}$ and $\mathrm{CeO}_{2}$ using the techniques of electron spin resonance, volumetric evaluation of carbon monoxide chemisorption, and gravimetric monitoring of hydrogen absorption. Ketones and aldehydes are reduced with hydrogen over a supported catalyst's containing nickel, aluminum and zirconium at temperatures from 60 to $150^{\circ} \mathrm{C}$ [34-36]. From literature it is obvious that supports used were silica, alumina oxide, carbon, kiesselger, and calcium carbonate [36].

\section{Y-Zeolite catalysts}

Acetone to isopropanol process for the production of phenol in addition to benzene is reacted with propene and iso-propanol to obtain a mixture of non-converted benzene, cumene and poly-isopropyl benzenes. The poly-isopropyl benzene fraction is then contacted with dealuminized Y-Zeolite to obtain cumene. Cumene is then converted into a mixture of acetone and phenol by-product acetone which is hydrogenated to isopropanol and recycled to the alkylation step. Even chloro substituted acetone i.e. 1-chloro acetone is reduced to 1-chloro 2-propanol over silica supported noble metal catalysts. Literature review shows that over $\mathrm{Rh} / \mathrm{SiO}_{2}$ 1-chloro acetone is transformed to acetone 1-chloro-2-propanol through addition of hydrogen chloride [37].

\section{Ruthenium catalysts}

Ruthenium finely divided is added or compounds of ruthenium are used which is reducible by hydrogen to finely divided elemental ruthenium [38]. Suitable reducible compounds include ruthenium oxide, ruthenium chloride, ruthenium nitrate, ruthenium acetate, ruthenium carbonate, ruthenium hydroxide.

\section{Hydrotalcite catalysts}

Hydrotalcites are solid base catalysts comprising of $\mathrm{M}(\mathrm{II})$ and $\mathrm{M}(\mathrm{III}) \mathrm{Mg}, \mathrm{Cu}, \mathrm{Ni}, \mathrm{Pd}, \mathrm{Pt}$, $\mathrm{Fe}, \mathrm{Co}, \mathrm{Mg}, \mathrm{Al}, \mathrm{Cr}, \mathrm{Cd}$ which forms mixed oxides by co-precipitation of homogeneous metals in bases. $\mathrm{CoMgAl}$ or $\mathrm{NiMgAl}$ layered double hydroxides, $\mathrm{Cu}$ $\mathrm{Cr}_{2} \mathrm{O}_{4} \mathrm{Cu}_{6} \mathrm{O}_{8} \operatorname{Ln}\left(\mathrm{NO}_{3}\right)$, and Pt/activated carbon. The resultant products are typically 2-propanol and methyl isobutyl ketone, diacetone alcohol, mesityl 
Table 3: Previous work for one-step synthesis of methyl isobutyl ketone from acetone ${ }^{31,37}$

\begin{tabular}{|c|c|c|c|c|}
\hline Catalyst & $\begin{array}{l}\text { Pressure } \\
\text { (atm) }\end{array}$ & $\mathbf{T}(\mathrm{K})$ & Conv (\%) & $\begin{array}{l}\text { Selectivity } \\
(\%)\end{array}$ \\
\hline Pd-KUZ & 20 & 393 & 50 & 94.5 \\
\hline $\mathrm{Pd}-\mathrm{CuO} / \mathrm{Al}_{2} \mathrm{O}_{3} / \mathrm{SiO}_{2}$ & 1 & $423-503$ & 30 & 60 \\
\hline $\mathrm{Pd}-\mathrm{CuO} / \mathrm{MgO} / \mathrm{SrO}$ & 20 & 433 & 38.5 & 93.6 \\
\hline $\mathrm{Pd}-\mathrm{Nb}_{2} \mathrm{O}_{5}-\mathrm{Al}_{2} \mathrm{O}_{3}$ & - & - & 28 & 90 \\
\hline Pd-oxides of $\mathrm{Ti}, \mathrm{Zr}, \mathrm{Cr}$ & 10 & 413 & 33.9 & 92.3 \\
\hline Pd-KUZFPP & 30 & $353-388$ & - & - \\
\hline $\mathrm{Pd}-\mathrm{C}-\mathrm{Nb}_{2} \mathrm{O}_{5}$ & 20 & 413 & 39.5 & 92.5 \\
\hline $\mathrm{Pd}-\mathrm{C}-\mathrm{Nb}_{2} \mathrm{O}_{5}$ & 10 & 413 & 30 & 91.7 \\
\hline Pd-oxides of Ce, Hf, Ta & 10 & 413 & 33 & 90.2 \\
\hline Pd-IER & 40 & $363-393$ & - & - \\
\hline Pd-CS-H-ZSM-5 & 1 & 523 & 41.9 & 82.4 \\
\hline $\mathrm{Pd}-\mathrm{Nb}_{2} \mathrm{O}_{5}$ & - & - & 41.8 & 93.5 \\
\hline Pd-oxides of $\mathrm{Zr}$ & - & - & 27 & 94.9 \\
\hline Pd-KS-IER & 50 & $373-403$ & - & 90 \\
\hline Pd-ZSM-5 & 50 & 443 & 40.25 & 95.36 \\
\hline Pd-IER & - & - & - & - \\
\hline $\mathrm{Ni}, \mathrm{Cu}, \mathrm{Co}-\mathrm{Ga}-\mathrm{Al}_{2} \mathrm{O}_{3}$ & - & 453 & 53.9 & 37.1 \\
\hline $\mathrm{Ni}-\mathrm{Al}_{2} \mathrm{O}_{3}$ & 1 & 373 & - & 95 \\
\hline Pd-ZSM-5 & - & - & - & - \\
\hline $\mathrm{SiO}_{2} / \mathrm{Al}_{2} \mathrm{O}_{3}=30$ & $6-60$ & 433 & 41.24 & 90.98 \\
\hline $\mathrm{Ni}-\mathrm{CaO}$ & - & 473 & $70-80$ & 60 \\
\hline $\mathrm{Cu}-\mathrm{MgO}$ & 1 & 653 & $60-80$ & $60-75$ \\
\hline Pt-HMF & 1 & 433 & - & - \\
\hline $\mathrm{Ni}-\mathrm{CaO}$ & - & - & $60-80$ & $50-60$ \\
\hline 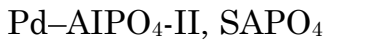 & - & - & - & - \\
\hline $\mathrm{Ni}-\mathrm{Al}$ phosphate & - & - & - & - \\
\hline Pd-(Zn)-H-ZSM-5 & 5 & $408-483$ & 55 & $83-94$ \\
\hline $\mathrm{Pd}-\mathrm{Nb}_{2} \mathrm{O}_{5}-\mathrm{SiO}_{2}$ & - & - & $30-35$ & $88-92$ \\
\hline $\mathrm{Ni}-\mathrm{CaO}$ & - & - & $60-70$ & 70 \\
\hline $\mathrm{Pd}-\mathrm{Al}_{2} \mathrm{O}_{3}$ & $40-90$ & $413-473$ & - & - \\
\hline Pt-H-ZSM-5 & 1 & 433 & - & - \\
\hline Pt-NaX & - & 713 & - & 70 \\
\hline Pd-H-ZSM-5 & 1 & 473 & 47.3 & 30.7 \\
\hline Pd-IER & $40-70$ & $353-373$ & - & - \\
\hline $\mathrm{Cu}-\mathrm{MgO}-\mathrm{Al}_{2} \mathrm{O}_{3}$ & - & - & 65.26 & 57.49 \\
\hline Pd-zeolite & - & - & 70 & 87.5 \\
\hline Pd-IER & - & 403 & 43.2 & 98.2 \\
\hline Pt-Sn-H-ZSM-5 & 1 & 433 & - & - \\
\hline $\mathrm{Pd}-\mathrm{C}$ & $1-20$ & 333 & - & - \\
\hline $\mathrm{Pd}-\mathrm{Ca}-\mathrm{Al}_{2} \mathrm{O}_{3}$ & - & - & - & - \\
\hline Amberlyst $\mathrm{CH}$ & $28-30$ & $403-423$ & $25-50$ & 70-90 \\
\hline $\mathrm{Pd}$ & 35 & 300 & 15 & 60 \\
\hline Pd-IER & $5-15$ & $373-453$ & - & - \\
\hline Pd-MCM-56 & - & - & 33.5 & 81.2 \\
\hline Pd-MCM-49 & - & - & 35.6 & 85 \\
\hline $\mathrm{Cu}-\mathrm{MgO}-\mathrm{Al}_{2} \mathrm{O}_{3}$ & 1 & 513 & 71.7 & 50.1 \\
\hline
\end{tabular}


Table 4: The following table summarizes some important characteristics of $\mathrm{NaBH}_{4} \& \mathrm{Li}$ $\mathrm{AlH}_{4}$ useful reagents [80].

\begin{tabular}{|c|c|c|c|}
\hline Reagent & Solvents & Functional groups & Reaction workup \\
\hline $\begin{array}{l}\text { Sodium } \\
\text { borohydride } \\
\mathrm{NaBH}_{4}\end{array}$ & $\begin{array}{l}\text { Ethanol,Aqueous } \\
\text { ethanol, } \\
15 \% \mathrm{NaOH}, \\
\text { diglyme }\end{array}$ & $\begin{array}{l}\text { Aldehdyes to alcohols } \\
\text { Ketones to alcohols }\end{array}$ & $\begin{array}{l}\text { Simple } \\
\text { Nuetralization and } \\
\text { extraction of } \\
\text { product }\end{array}$ \\
\hline $\begin{array}{l}\text { Lithium } \\
\text { Aluminium } \\
\text { Hydride }\end{array}$ & Ether, THF & $\begin{array}{l}\text { Aldehydes to alcohols } \\
\text { Ketones to alcohols } \\
\text { carboxylic acids to } 1^{\circ} \text { - } \\
\text { alcohols } \\
\text { esters to alcohols } \\
\text { epoxides to alcohols } \\
\text { nitriles \& amides to } \\
\text { amines } \\
\text { halides \& tosylates to } \\
\text { alkanes } \\
\text { most functions react. }\end{array}$ & $\begin{array}{l}\text { Careful addition of } \\
\text { water and removal } \\
\text { of salts and } \\
\text { extraction of } \\
\text { product. }\end{array}$ \\
\hline
\end{tabular}

oxide, di-isobutyl ketone, propane, and 2methylpentane in ratio's which depend's on reaction conditions [17-20]. Hydrotalcite catalysts which have vast application for organic transformations cyanoethylation, hydrogenation, dealkylation, oxidation's, Knoevenegal, aldol, epoxidation, ring opening of epoxides. $\mathrm{Mg}-\mathrm{Al}$ supported with $\mathrm{Pd}$ and $\mathrm{Pt}$ hydrotalcites like solid bases are active for selective reduction of acetone to 2-propanol which get condensed to produce MIBK and DAA. With low selectivity to IPA [38]. Wide range of heterogeneous catalysts have been used for the reduction of acetone to methyl isobutyl ketone which are represented in table 3 below. Alkali-catalyzed aldol condensation of acetone to diacetone alcohol, elimination of water leads to 4methyl-3-penten-2-one (mesityl oxide) [24]. During hydrogenation of acetone intermediate mesityl oxide leads to 4-methyl-2-pentanone (methyl isobutyl ketone) leads to 4-methyl-2-pentanol. Diacetone alcohol which is reduced directly to hexylene glycol. The desired product iso-propanol can also react further with the elimination of water to form the undesired di-isopropyl ether [39].

Catalytic process thrives on process parameters (i.e. total turnover number) for acetone hydrogenation have not been specifically reported in literature in short without prior precedent and thus of considerable interest and acetone hydrogenation catalysts which operates at $100{ }^{\circ} \mathrm{C}$, with an activity $\geq 8.5 \mathrm{~S}-16$. A new area of nanoparticulate $\mathrm{Au}$ supported on various oxides. The particle size in this case is critical to the catalytic performance, bulk $\mathrm{Au}$ is inactive but particles on the nanometer scale have shown room temperature activity for the oxidation of $\mathrm{CO}$ to $\mathrm{CO}_{2}$ [39]. The $\mathrm{Au} /$ oxide interface requires large unit cells to be constructed so that the periphery of the Au cluster can be included without interference between periodic images. Au and the support oxide can significantly influence the electronic character of the metal particles. This is particularly important if the oxide surface is defective. Figure 6 shows the charge transfer from a surface oxygen vacancy to the $\mathrm{Au} 10$ cluster. This gives a cluster with an overall negative charge and we are currently investigating the effect this has on the adsorption and vibration of reactant molecules.

\section{Parametric Analysis}

During the up-gradation of acetone hydrogenation process various paramaters are taken into account which are given below. 1. Effect of solvent 2.Mass transfer phenomena 3 Effect of hydrogen pressure 4. Effect of moisture concentration 5. Effect of temperature 6. Effect of catalyst loading. 


\subsection{Effect of solvent on hydrogenation of acetone to Isopropanol}

Solvents plays a major contributor in a single step or multistep chemical process. The solvent used methanol, ethanol, propanol, n-butanol, ethylene glycol, propylene glycol, diethylene glycol, and triethylene glycol are useful solvents for hydrogenation reactions. Other essential solvents in series of ethers such as di-isopropyl ether, dibutyl ether, dimethyl ether, diglyme, triglyme. Aprotic polar solvents such as dimethyl formamide, dimethyl acetamide, acetonitrile, dimethyl sulfoxide, saturated hydrocarbons such as hexane, heptane, cyclopentane, cyclohexane, etc. Choudary et al [40] reported reduction of a wide variety of aromatic and heterocyclic aldehydes to the crorresponding alcohols with $\mathrm{Ni}$-Al calcined hydrotcalcite in hydrgoen atmosphere examined wide variety of solvents notable were tetrahydrofuran, ethyl acetate which gave good result's for conversion with $100 \%$ selectivity of aldehydes to alcohols at $80^{\circ} \mathrm{C}$ [40].

\subsection{Effect of hydrogen pressure}

The effect of hydrogen pressure plays an important function in hydrogenation reaction's depending on the process parameters where less hydrogen pressure is consumed at times more hydrogen pressure is required which depends upon the active sites of the catalysts. The solubility of hydrogen varies with pressure and hence it may influence the reaction kinetics. In order to study

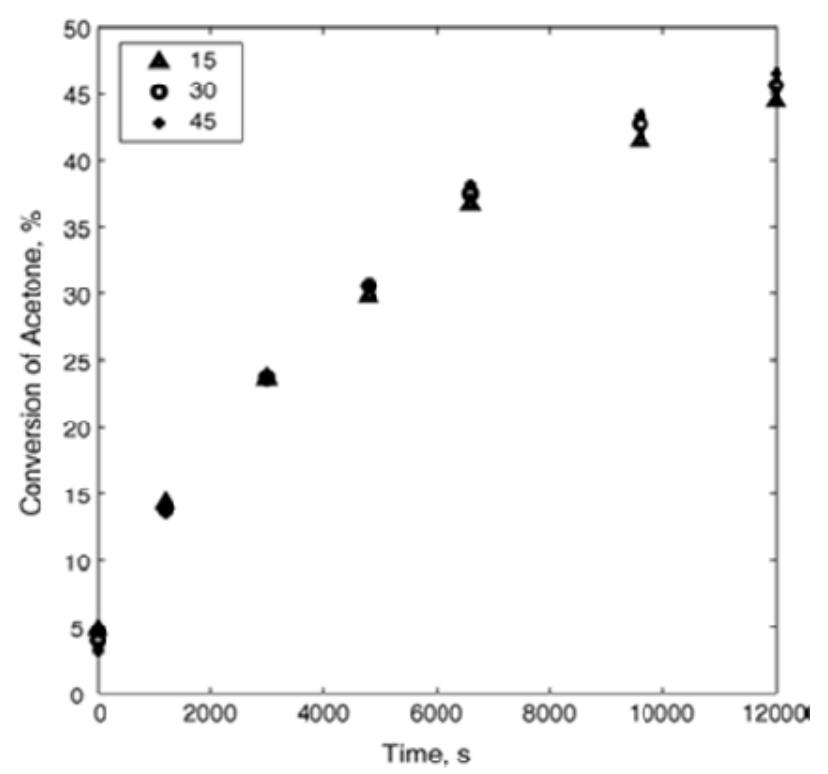

Figure 3. Effect of hydrogen pressure on the reaction kinetics. Temperature $=393 \mathrm{~K}$; catalyst loading $5 \% \mathrm{w} / \mathrm{w}$ of acetone; pressure in bar

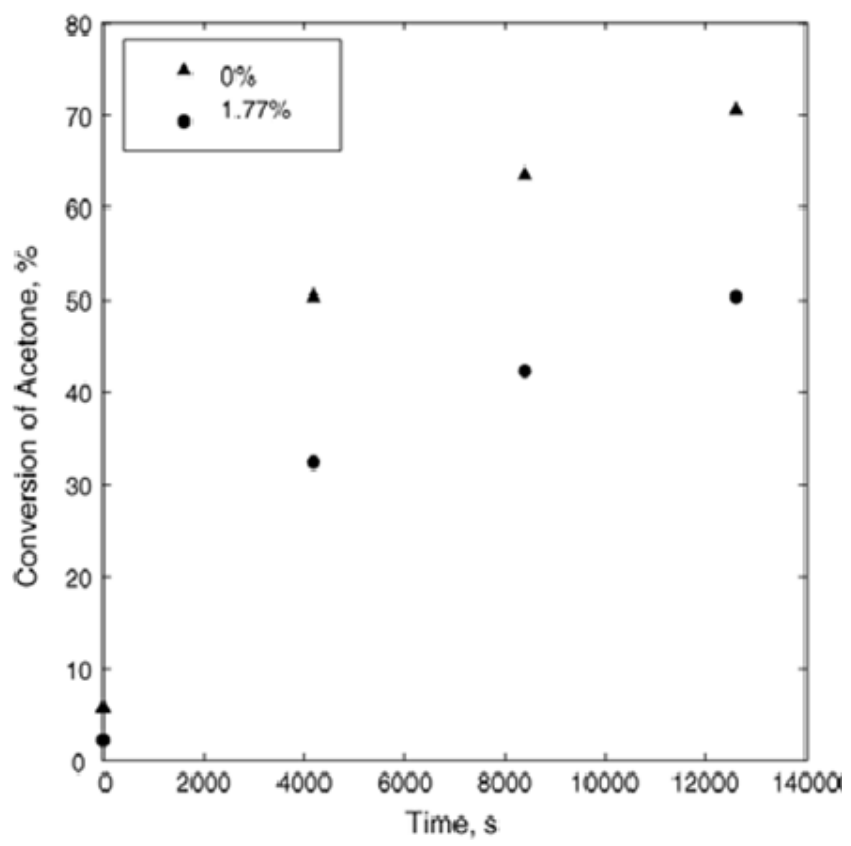

Figure 4: Effect of water addition. Temperature = $413 \mathrm{~K}$; catalyst loading: $5 \% \mathrm{w} / \mathrm{w}$ of acetone; pressure $=30$ bar water concentration in wt $\%$.

the effect of hydrogen pressure,35 reactions were performed in a range of 15-45 bar. It's pragmatic there is no effect of hydrogen pressure on the reaction kinetics, as shown in Fig.1. One of the possible reasons for this is that the amount of catalysts in the system is small and the active sites are not sufficient.

\subsection{Effect of moisture concentration}

The exact role of water in the kinetics, following experiments with and without water. As shown in Fig 2 below, presence of water in the reaction system causes reversible catalyst deactivation; hence low rates of reactions are observed for the reaction with initial moisture. This implies the rate of mesityl oxide formed is affected due to the inhibition of sulfonic acid groups by polar components like water. This phenomena is well known for many reactions on ion exchange resins. However, mesityl oxide formation is still followed by its instantaneous hydrogenation to methyl isobutyl ketone. In short, the rate of formation of methyl isobutyl ketone is equal to the rate of formation of mesityl oxide without moisture. This suggests simultaneous removal of mesityl oxide along with the removal of water by some mean's is necessary to enhance the reactor performance further. Therefore, this system is superior candidate for multifunctional reactor system like 


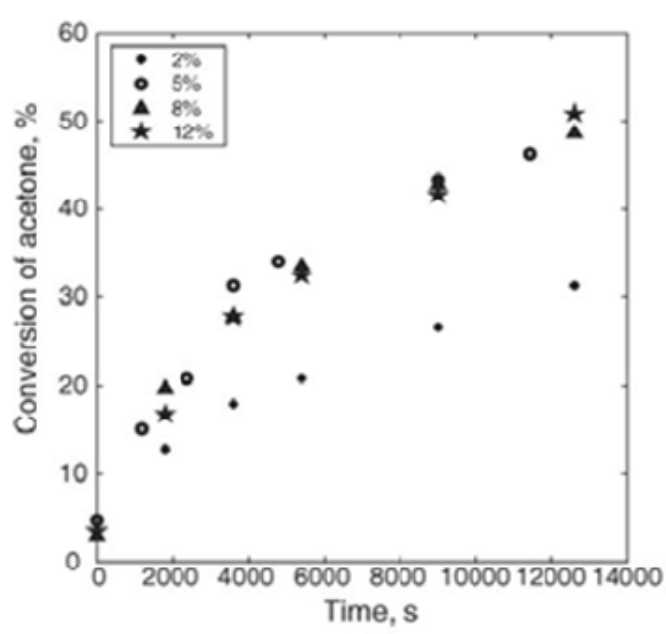

(a)

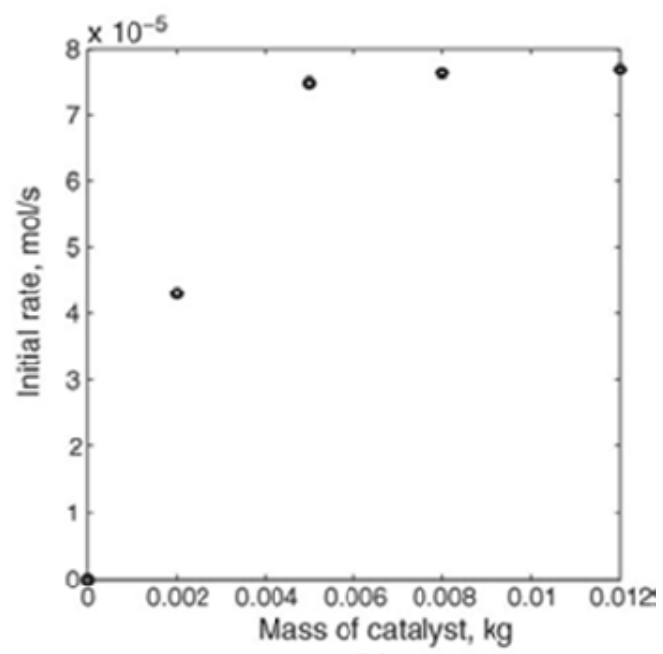

(b)

Figure 5 : Effect of catalyst loading on (a) reaction kinetics (b) initial rate. Temperature $=393 \mathrm{~K}$; catalyst loading: in w/w of acetone; pressure $=30 \mathrm{bar}$

reactive distillation or reactive adsorption. Since not much work is, reported in literature except for few references [36] on this aspect.

\subsection{Effect of temperature}

The effect of temperature was studied over a range of 373-413K for conversion of acetone at different temperatures. With increase in temperature, conversion of acetone increases at the cost of reduced selectivity towards methyl isobutyl ketone. At relatively high temperatures, mesityl oxide is likely to react with acetone to form heavy components like isophorone and other condensation products. The thermal stability of the present catalyst for acetone reduction, and stable up to $423 \mathrm{~K} 22$.

\subsection{Effect of catalyst loading}

Effect of catalysts loading plays an important role specially in hydrogenation reactions. The reactions were performed at different catalyst loadings $(2-12 \% \mathrm{w} / \mathrm{w}$ of acetone) and the rate of reaction is enhanced with different \% of catalyst loading which is increased from $2 \%$ to $5 \% \mathrm{w} / \mathrm{w}$ of acetone. However, the rate of reaction reaches saturation above the catalyst loading of $5 \% \mathrm{w} / \mathrm{w}$ of acetone, as shown in Fig. 3. Moreau et al.[41] reported non-linear influence of catalyst loading on the rate of hydrolysis of acetals over $\mathrm{H}$ Montmorillonite and strong cation exchange resin. It is expected the number of catalytic sites above a particular catalyst loading becomes excessive and hence the rate becomes insensitive for further increase in catalyst loading. But this effect is not because of the diffusion limitations as variables such as stirrer speed do not influence the overall rate of reaction under these conditions. Usually such effect can be explained only through the rigorous thermodynamic models of adsorption. A theoretical explanation for the same is lacking in the literature though some evidences have been reported [41].

\section{Case Study 1: Hydrogenation of Acetone to Isopropanol using Copper Catalysts}

\section{Effect of Copper catalysts}

Raney nickel, (Ni/Al) and copper based catalysts, e.g., copper-chromium; raney copper, copper zinc, nickel based catalysts ex: nickel catalysts from nickel oxide on alumina, silica support and tailoring it through a reduction treatment. Cunningham et.al [42] reported earlier that $\mathrm{Cu}-\mathrm{TiO}_{2}$ is effective system for the reduction of acetone to 2-propanol which requires high temperatures at $453 \mathrm{~K}$. At low temperatures aldol condensation which mainly gives $\mathrm{C}_{6}$ and $\mathrm{C}_{9}$ compounds. Liquid phase hydrogenation of acetone in stirred tank reactors using Raney metal catalysts have been employed but these processes often suffer from poor catalyst productivity [41-42]. When the liquid phase hydrogenation process is carried out employing sponge or Raney metal catalysts containing chromium as a promoter, one unexpectedly finds greater catalyst productivity or activity. Earlier [22] reported on nickel-containing catalyst ( $10 \%$ by weight of nickel) on a neutral $\alpha$ $\mathrm{Al}_{2} \mathrm{O}_{3}$ support used showed some activity. Byproducts of the hydrogenation reaction include: methyl isobutyl ketone, 4-methyl-2-pentanol, 
hexylene glycol and other high-boilers whose identities were not determined.

A sample of copper chromite was prepared by co-precipitation of the mixed hydroxide from a solution of the corresponding nitrates by ammonia solution; and thermally decomposed at $900^{\circ} \mathrm{C}$. XRD examination showed sample was essentially a pure compound with the structure of a tetragonally distorted spinel [44]. The catalytic behavior of chromite for hydrogenation of acetone to isopropyl alcohol was studied using a pulse flow installation in a fluidized catalyst bed. Yurieva [29] studied the nature of interaction of hydrogen with copper chromite catalysts for hydrogenation of acetone to isopropanol. It was found that initial and final temperature for reduction of copper chromite catalysts which determine's the nature of interaction between hydrogen and chromite. When a sample of copper chromite is kept at $500^{\circ} \mathrm{C}$ in air flow and then reduced at a higher temperature, a chromite of the delafossite structure containing $\mathrm{Cu}$ was formed [44]. When copper chromite was heated gradually from room temperature to above $450^{\circ} \mathrm{C}$ in hydrogen flow, this resulted in the decomposition of chromite to produce copper metal and chromia [45]. Yurieva [29] studied the kinetics of interaction between hydrogen and chromite at temperatures ranging from 200 to $300^{\circ} \mathrm{C}$ [39-40] demonstrated a dependence of the interaction rate on the extent of reduction of chromite. The rate of interaction of copper ions with hydrogen on the surface layer increased as reduction, reached a maximum and then decreased. The maximum rate at $300^{\circ} \mathrm{C}$ was attained when the quantity of hydrogen consumed corresponded to the reduction of $0.3 \%$ of the copper ions of the chromite (ca. $60 \%$ of the surface copper ions). Only part of the hydrogen consumed formed water. The fraction of water-producing hydrogen also depended on the extent of reduction of the chromite; the greatest amount of water ( $40 \%$ with respect to the adsorbed hydrogen at that moment) was formed at the earliest moment of exposure of the sample to hydrogen, when the extent of reduction of the chromite was low. As the chromite was reduced, the fraction of water-producing hydrogen decreased rapidly, being less than $4 \%$ at an overall hydrogen uptake corresponding to the reduction of $3 \pm 4 \%$ of the copper ions.

The total hydrogen uptake corresponded to reduction of $3 \%$ of the copper ions of the chromite after a $2 \mathrm{~h}$ run in the temperature range $20 \pm 200^{\circ} \mathrm{C}$ and to $65 \%$ of the copper ions after same period of time in the temperature range $25 \pm 320^{\circ} \mathrm{C}$. There was slow hydrogen uptake at temperatures $20 \pm 200^{\circ} \mathrm{C}$ and a much higher rate of uptake at the temperatures $25 \pm 300^{\circ} \mathrm{C}$. Selective dehydrogenation of 2-propanol and hydrogenation of acetone with $\mathrm{Cu}$ metal, $\mathrm{CuO}$, and $\mathrm{Cu}_{2} \mathrm{O}$ with high conversions and selectivities under different conditions were used [45]. SEM analysis of copper chromite samples of the dark field of $\mathrm{CuO}$ particles have identical orientation amd calcined at $320^{\circ} \mathrm{C}$ in $\mathrm{H}^{2}$ and and $450^{\circ} \mathrm{C}$ reveals Fig 6 .

\subsection{Mechanism}

A plausible reaction mechanism for hydrogenation of acetone to isopropanol occurs through a non-competitive chemisorption of acetone and hydrogen, which result's in forming: (a) A stronger chemisorption of acetone with respect to hydrogen and (b) Steric hindrance of the large acetone molecules which tend's to exclude one another from adjacent sites leaving empty chemisorption sites of hydrogen. Yurieva et. al [29] reported a brief mechanism is discussed in hydrogenation of carbon oxides and acetone is proposed resulting in the ability of copper ions for reversible transformations to generate copper metal and protons. Activation of acetone and $\mathrm{CO}_{2}$ can be achieved through their interaction with $\mathrm{Cu} 0$, and activation of $\mathrm{CO}$ through its interaction with oxygen-containing sites of $\mathrm{Cu}+1--\mathrm{O}---\mathrm{Cu}+1$

Table 5: Oxygen uptakes, dispersions, and crystallite sizes for copper catalysts ${ }^{27}$

\begin{tabular}{|c|c|c|c|c|c|}
\hline catalyst & $\begin{array}{c}\mathrm{Cu} \\
\text { content } \\
(\mathrm{Wt} \%)\end{array}$ & Pretreatment & $\begin{array}{c}\text { Uptake } \\
\text { ( } \mu \text { mol of } O / \\
\text { g cat) }\end{array}$ & $\begin{array}{l}\text { Dispersion } \\
\text { (D) }\end{array}$ & $d_{p}(n m)$ \\
\hline $0.5 \mathrm{Cu}$ & 0.5 & $2 \mathrm{~h}, 873 \mathrm{k}$ & 29.5 & 0.75 & 1.5 \\
\hline $5 \mathrm{Cu}$ & 4.8 & $2 \mathrm{~h}, 673 \mathrm{k}$ & 30.7 & 0.081 & 14 \\
\hline $20 \mathrm{Cu}$ & 20.5 & $2 \mathrm{~h}, 673 \mathrm{k}$ & 16 & 0.010 & 110 \\
\hline $\mathrm{Cu}-1800 p$ & 42 & $4 \mathrm{~h}, 673 \mathrm{k}$ & 1240 & 0.366 & 3.0 \\
\hline $\mathrm{Cu}$ powder & 100.0 & $2 \mathrm{~h} 673 \mathrm{k}$ & 1 & $1.2 \times 10^{-4}$ & 9000 \\
\hline
\end{tabular}


type which are formed after oxidation of a portion of $\mathrm{Cu} 0$ with carbon dioxide.

Surface synergisms studies were reported by Cunningham et. al [43] between copper and its oxides for hydrogenation of acetone to isopropanol at $423-523 \mathrm{~K}$ over unsupported cuprous oxide, copper metal and cupric oxide. An activation energy of ca. $143 \mathrm{~kJ}$ mol-1 is deduced for induction of active sites on $\mathrm{CuI}_{2} \mathrm{O}$. Cunningham et. al [43] reported studies conducted from temperatureprogrammed reduction (TPR) that acetone vapour inhibits the reduction of cuprous oxide, whereas isopropanol vapour enhances it. The extent of correlation of these TPR results indicates that induction periods for the growth of $\left(+\mathrm{H}_{2}\right)$ activity, and with pseudo-stationary-state levels of this activity are considered. It leads to a model in which $\left(+\mathrm{H}_{2}\right)$ activity over the ex- $\mathrm{CuI}_{2} \mathrm{O}$ samples is related to the density of active surface locations which feature $\mathrm{CuO}_{\mathrm{x}}$ and $\mathrm{CuI}_{\mathrm{y}}$ centers in close position. The difficulty of attaining an adequate density of such locations depends strongly upon the reaction temperature and upon the degree of preoxidation/prereduction of each $\mathrm{Cu}_{2} \mathrm{O}$ sample. They made comparisons with profiles for $\left(+\mathrm{H}_{2}\right)$ activity over $\mathrm{Cu}_{2} \mathrm{O}$ and $\mathrm{CuO}$ metal powders with results from TPR over $\mathrm{Cu}_{2} \mathrm{O}$ in the vapours of acetone or isopropanol. These studies confirms that acetone vapours get reduced on the surface of the catalysts during the catalytic process which confirm formation of isopropanol as the final product.

\subsection{Surface synergisms studies of $\mathrm{Cu}, \mathrm{CuO}$, and $\mathrm{Cu}_{2} \mathrm{O}$ and Kinetic modeling}

Surface synergisms studies plays important major role in evaluating activity of the catalysts during the reaction. Surface synergisms were studied between copper and copper oxide for acetone reduction which is employed as the test reactions to compare the $+\mathrm{H}_{2}$ and or $-\mathrm{H}_{2}$ activities of individual valence states of copper upon appropriately pretreated surfaces of $\mathrm{Cu}_{2} \mathrm{O}, \mathrm{CuO}$ and copper metal powders [43].

Pre-treatments of copper metal samples were made with flowing gases in which oxygen content had been diminished to low levels, thus prereductions were made with chemically pure $\mathrm{H}_{2}$ or $3 \% \mathrm{H}_{2}$ in $\mathrm{N}_{2}$, additionally purified by flowing over copper turnings at $573 \mathrm{~K}$ and subsequent drying. Sample out gassings aimed at removal of water or other adsorbed impurities were made in argon with especially low levels of oxygen impurity levels, it's only realistic to recognize that copper metal samples thus pre-treated were unlikely to be completely oxygen-free, since in $1 \mathrm{ppm}$ of residual oxygen would add upto an exposure of 2.7 Torr sec during $1 \mathrm{~h}$ continuous flow. Chemically pure argon, $\mathrm{H}_{2}, 3 \% \mathrm{H}_{2}$ in $\mathrm{N}_{2}$ or $\mathrm{O}_{2}$ gases were considered adequate for pre-treatment or carrier gas flows over $\mathrm{CuO}$ or $\mathrm{Cu}_{2} \mathrm{O}$ [43].

The pretreated copper oxide samples of surface exhibited that the surface were effectively free of carbon or other impurities that $\mathrm{Cu}$ (II) strongly pre-dominated on the surface region of $\mathrm{CuO}$. The existence of the shakeup satellite (at 940-945 V) uniquely characteristic of the $\mathrm{Cu}$ (II) valence state was not only observed, but also appropriate ratio of its intensity to the main. And $\mathrm{Cu}$ (I) was predominant valence state in surface regions of $\mathrm{Cu}_{2} \mathrm{O}$, evident by the absence of any significant shakeup satellite (at 940-945 V) uniquely characteristic of the $\mathrm{Cu}$ (II) valence state was not only observed, but also appropriate ratio of its intensity to the main $2 \mathrm{p} 3 / 2$ XPS peak at $933.6 \mathrm{v}$; evident by the absence of any significant shakeup satellite in its XPS features, characteristics Cu (I). It is evident from this data reported that activity developed at higher integrated exposures to alcohol vapour, but only after an induction period. Over previously well oxidized $\mathrm{CuO}$ the duration of such induction depended upon the extent to which the sample was deoxygenated at $473 \mathrm{~K}$ in an argon flow. Prior to pre-reduction of the $\mathrm{Cu}_{2} \mathrm{O}$ samples in $\mathrm{H}_{2}$ at $423 \mathrm{~K}$ sharply increased the maxim level of ($\mathrm{H}_{2}$ ) conversion attainable but, unlike the $\mathrm{CuO}$ system such maximum activity was short lived [43].

A process for the catalytic hydrogenation of acetone by feeding hydrogen and acetone in liquid phase to a reactor having a fixed catalyst bed from its top to form a concurrent gas/liquid flow and maintaining a trickle bed state is preferred process being used [43]. The oxygen uptakes, $\mathrm{Cu}$ dispersion and the crystallite sizes are calculated from the oxygen adsorption experiments for each catalysts following various pre-ptreatments conditions mentioned in table 1 . Which is verified by X-ray Diffraction [13]. Where detectable copper was present on $\mathrm{CuO}$ phase in these catalysts following the corresponding pre-treatments. The thin (ca. 1 $\mathrm{nm})$ surface layer of $\mathrm{Cu}_{2} \mathrm{O}$ created during passivation could not be detected by XRD, consistent with previous characterization of these $\mathrm{CuSiO}_{2}$ catalysts. The comparison of catalytic activity was made at reaction temperature of 423 $\mathrm{K}$. All the catalysts utilized in this study exhibited considerable deactivation during acetone hydrogenation, and 2-propanol was dominant product $(>99 \%)$. In case of $5 \mathrm{Cu}, 20 \mathrm{Cu}$ and $\mathrm{Cu}-1800$ $\mathrm{P}$, a small amount $(<1 \%)$ of a light gaseous product 
(possibly a light hydrocarbon) was observed during the first few minutes on stream, whereas for $0.5 \mathrm{Cu}$ and $\mathrm{Cu}$ powder, isopropanol was the only detectable product throughout the duration of the reaction [15].

\section{Case Study 2: Hydrogenation of Acetone to Isopropanol using Nickel Hydrides}

H. C. Brown [49] described a 40 year odyssey in the development of wide range of Nickel boride catalysts, complex nucleophillic alumino and borohydrides from their electrophilic counterparts borane. Sodium borohydride reacts with first order kinetics involving a rate determining hydride attack on the carbonyl carbon, but the nature of the interaction of the metal cation or boron atom with the carbonyl oxygen is unknown. An ab initio theoretical study of borohydride addition to formaldehyde concluded that the traditional $[2+2]$ four center transition state, with simultaneous $\mathrm{CH}$ and $\mathrm{BO}$ bond formation $\mathrm{BH}$ bond breaking was not

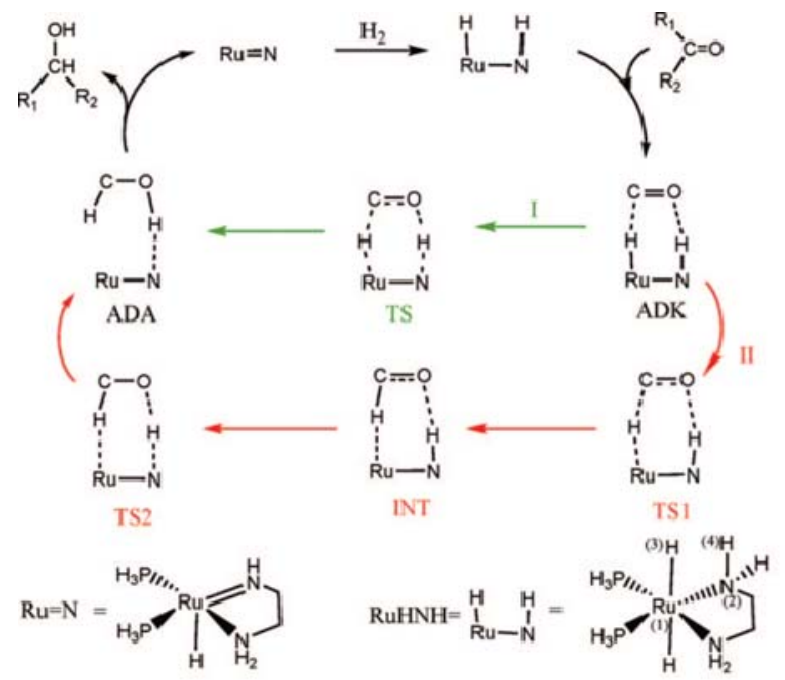

(b) Structures of eight substrates.<smiles>CC(C)=O</smiles>

Al<smiles>O=C(O)c1ccccc1</smiles>

B1<smiles>CC(=O)O</smiles>

A2<smiles>CC(=O)c1ccc(F)cc1</smiles>

B2<smiles>[C+]C(C)=O</smiles>

A3<smiles>CC(=O)c1cc(F)c(F)c(Br)c1</smiles><smiles>CC(=O)C(F)(F)F</smiles>

A4

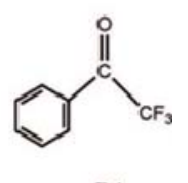

Scheme 2: (A) Generalized Catalytic Cycle for Ketone Hydrogenation Catalyzed by Ru Bifunctional Complex and (B) Structures of 8 substates is presented

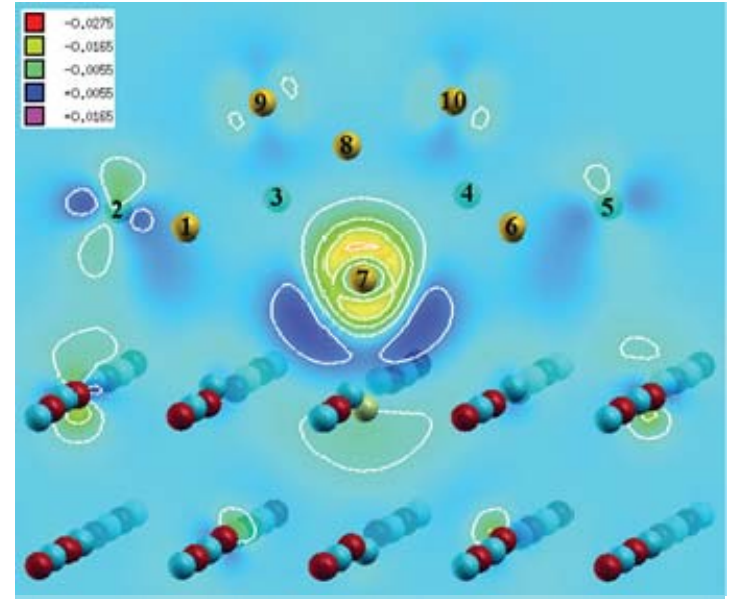

Figure 6 : A Au10 cluster adsorbed at a surface oxygen defect on $\mathrm{MgO}(001)$ the contour plot shows the transfer of charge from the defect to the central $\mathrm{Au}$ atom of the cluster.

the optimum representation [48]. Zinc-modified cyanoborohydride, prepared from anhydrous zinc chloride and sodium cyanoborohydride in the ratio 1:2 in ether, selectively reduced aldehydes and ketones but not acids, anydrides, esters and tertiary amides were reduced [49]. Few examples of aldehydes and ketones reduction's are presented in table 5 using the reagents mentioned above. Well established system of Ni boride complex i.e. $\mathrm{NiCl}_{2} / \mathrm{NaBH} 4 /$ polymer catalysts. Borohydrides have been extensively used in organic synthesis comprising of various metals, notable being nickel boride which is already mentioned above in discussion. Nickel boride is known to exhibit a high catalytic activity comparable to the activity of Raney nickel in the hydrogenation of a carboncarbon double bond [50].

The hydrogenation of a compound possessing a carbon-oxygen double bond, namely, carbonyl compound, chalcone for the production to the corresponding alcohol is of great industrial significance [51]. Alkali metal borohydrides commonly used sodium borohydride and potassium borohydride. Nickel Boride colloid exhibits high catalytic activity in the hydrogenation of carbonyl compounds by causing a nickel salt to react with alkali metal borohydride in alcohol solvent in the presence of an alcohol-soluble polymer intended as a protective colloid and subsequently adding a basic substance to the resultant reaction mixture, or by causing a nickel salt to react upon an alkali metal borohydride in an alcohol containing an insoluble basic substance in the presence of an alcohol-soluble polymer. 
The excess alkali borohydride is decomposed to produce a large amount of sodium borate, which is liable to upset the stability of colloidal dispersion and induce precipitation of colloidal particles [51]. The high catalytic activity of nickel boride colloid obtained by this invention exhibits in reduction of carbonyl compounds is fully manifested on condition that nickel boride forms a homogeneous colloidal state and the colloid is used in the presence of a basic substance. Use of a mixture of finely divided particles of nickel boride with a base brings about no catalytic activity in the hydrogenation of a carbonyl compound [51]. Nickel boride catalysts which have been developed by Brown [50] have been extensively studied for hydrogenation with wide range of functional groups in organic synthesis comprising of aliphatic and aromatic compounds.

It is well known that nickel boride is formed by reacting nickel chloride or any nickel salt's with sodium borohydride in methanol with spontaneous evolution of hydrogen i.e. black precipitate is formed during reduction of acetone to isopropanol. Recently reported by Jonnalagadda et.al [50-51] nickel boride silica catalysts used for the reduction of aldehydes, ketones, nitroaroamtics, alkenes, and reductive aminations reactions to the corresponding products with excellent conversions and $100 \%$ selectivity at low temperatures $0-10^{\circ} \mathrm{C}$ which took less duration of time to complete the reactions which proved to be superactive catalysts for reduction reactions at low temperature. Variety of substrates were conducted for catalytic activity and gave good conversions with 100\% selectivity owing to the remarkable activity of 5 and $10 \%$ $\mathrm{Ni} / \mathrm{SiO}_{2}$ catalysts which were prepared by impregnation method reported by Jonnalagadda et. al [51-53]. The catalysts were characterized by XRD, IR, BET, and SEM instruments. The analysis results showed excellent activity. The literature data showed that acetone hydrogenation

\section{Frontiers in Molecular Catalysis Science}
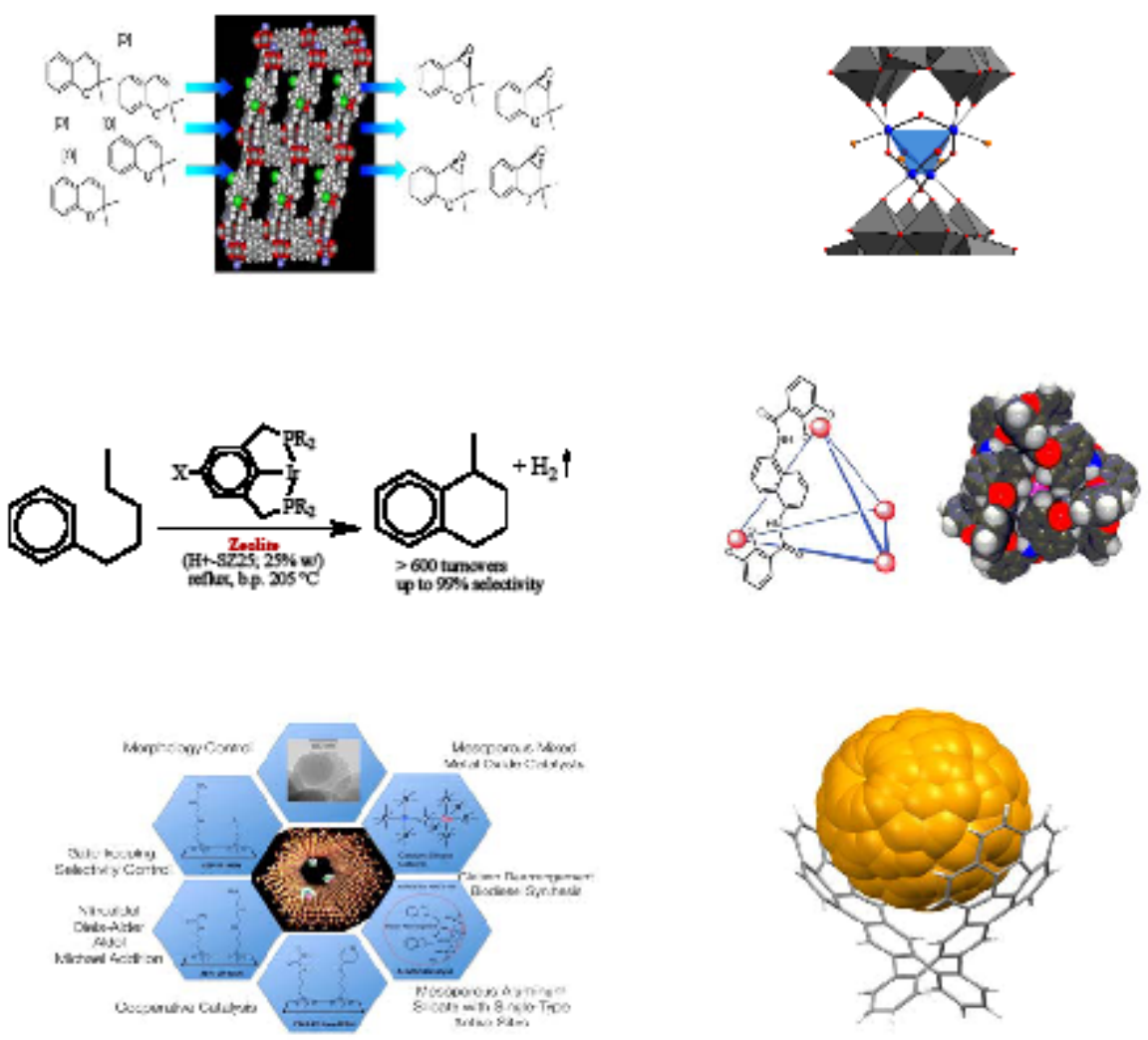

Figure7: Various catalysts and variety of complexes are developed for organic transformations 

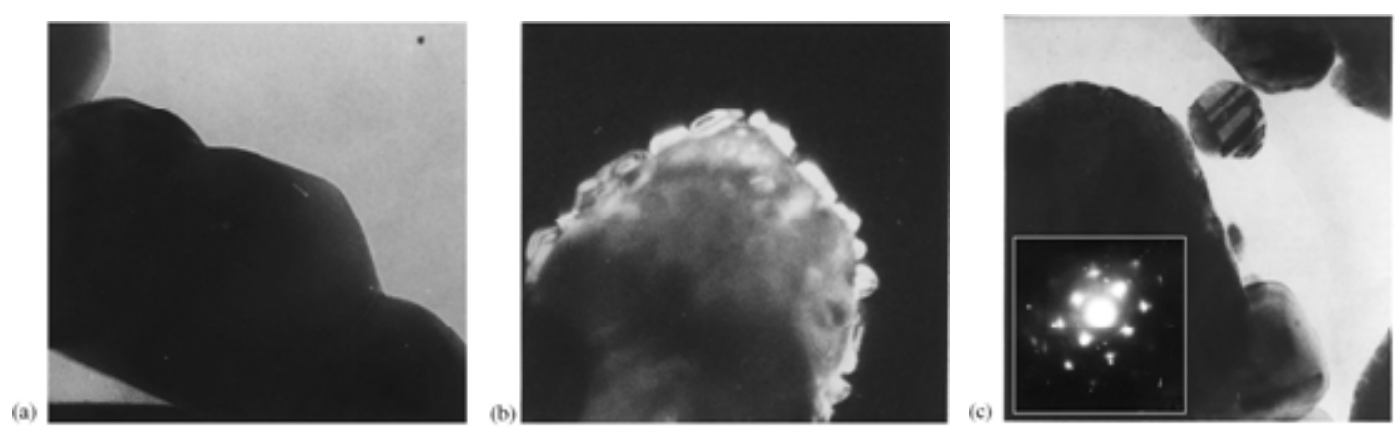

Figure 8: Electron microscopic images (x400 000) of the samples: initial $\mathrm{CuCr}_{2} \mathrm{O}_{4}$ (a) reduced in $\mathrm{H}_{2}$ at $320^{\circ} \mathrm{C}$, the dark-field image of $\mathrm{Cu} 0$ particles with identical orientation (b) and reduced in $\mathrm{H}_{2}$ at $450^{\circ} \mathrm{C}(\mathrm{c})$.

process have many drawbacks such as conversion, selectivity, atom economy, ecofreindly, choice of proper catalysts and reaction conditions.

Conclusions for the section on more general homogeneous versus heterogeneous catalysis question. However it must be noted that the guideline should be for ones own, creative thinking and approach for the specific true catalysts determination and catalysts at the hand. The central tenants of the methodology should still apply: (1) Find what form or forms of the precursor materials take in a sample of the resting state's of the catalyst. (2) Perform kinetic studies from resting state to determine which are the kinetically competent/dominant species. (3) The ideal goal in this updated approach to the homogeneous versus heterogeneous catalysis" problem is the simultaneous spectroscopic and kinetic analysis of a catalyst at the desired or normal operating conditions.

\section{Summary}

The key points from the introduction section are:

1. Acetone to isopropanol hydrogenation catalysts made with group's of 8-10 transition metal precatalysts, Raney Nickel, $\mathrm{Ni} / \mathrm{Al}_{2} \mathrm{O}_{3}, \mathrm{Ni} / \mathrm{SiO}_{2}, \mathrm{Ni}$ or $\mathrm{Co}-\mathrm{Al}_{2} \mathrm{O}_{3}, \mathrm{Pd}, \mathrm{Rh}, \mathrm{Ru}, \mathrm{Ni}, \mathrm{Re}, \mathrm{Co}$ or $\mathrm{Fe} / \mathrm{Al}_{2} \mathrm{O}_{3}$ (or supported on $\mathrm{SiO}_{2}$ or $\mathrm{MgO}$ ) and $\mathrm{CoMgAl}$ or $\mathrm{NiMg} \mathrm{Al}$ layered double hydroxide, $\mathrm{Cu}$ metal, $\mathrm{CuO}, \mathrm{Cu}_{2} \mathrm{O}, 0.5 \% \mathrm{Cu} / \mathrm{SiO}_{2}, 4.8 \% \mathrm{Cu} / \mathrm{SiO}_{2}$, and $20.5 \% \quad \mathrm{Cu} / \mathrm{SiO}_{2}, \quad \mathrm{Cu} / \mathrm{CrO}_{3}, \quad \mathrm{Cu} / \mathrm{Al}_{2} \mathrm{O}_{3}$ and $\mathrm{Pt} /$ carbon are important for the industrial hydrogenation of acetone.

2. Despite their relatively long history of industrial use, there is a need for an improved fundamental understanding of acetone hydrogenation catalysts. The innovative idea in understanding should improve in turn, drive further rationally-directed synthetic, mechanistic, and industrial improvements.

3. The key general areas investigated in the literature can be categorized as: (1) The variables important to catalyst synthesis and their effect on catalyst properties, particularly hydrogenation activity. (2) The reaction between the transition metal pre-catalyst and co-catalyst components. (3) The compositional and structural nature of the active catalyst species, and (4) The mechanism of catalytic hydrogenation.

\section{Acknowledgements:}

Author thank's Prof Saeed Al Zahrani for encouragement for this review article at college of engineering, Department of Chemical Engineering at King Saud University.

\section{References}

[1] John Wiley and Son, (1976) Kirk-Othmer: Encyclopedia of Chemical Technology, 3rd Edition, vol. 1, 179-182

[2] (a) A. M. W. Wojick, et. al; (2001) J. Phys, D: Appl. Phys, 34, 660-664. (b) N. Meng et. al; (1997) Int. J. Hydrogen Energy, 22, 361-362.

[3] F. Rositani, et. al; (1985) J. Chem. Tech and Biotech, 35A, 234-238.

[4] J. Cunningham, et. al; (1986) J. Catal 102, 160-171.

[5] R. A. W. Johnstone, et. al; (1985) Chem Rev, 85, 129157.

[6] S. Narayanan, et. al; (1996) Faraday Trans 1, 231-235.

[7] S. Ozkar et. al; (2005) J. Amer Chem Soc 127, 48004808.

[8] L. C. Anderson, et. al; (1942) J. Amer Chem Soc, 64, 1456-1459.

[9] K. Haack, et. al; (1997)J. Catal, 36,285-288.

[10] W. Reith, et. al; Stud Surf. Sci. Catal. (1991) 59, $487-$ 494.

[11] J. Simonikova, et. al; (1973) J. Catal 29, 412-420. 
[12] S. Talwalkar, et. al; (2006) Appl. Catal A: 302, 140-148.

[13] A. A. Nikolopoulos, et. al; (2005) Appl. Catal A: 296, 128136.

[14] G. M. R. van Druten and V. Ponec. (2000) Appl. Catal A: 191, 153-162.

[15] Y. Ando, et. al; (2005) J. Phy. Chem. B 109,2086-2089.

[16] S. Ozkar et. al; (2005) J. Amer Chem Soc 127, 48004808.

[17] L. C. Anderson, et. al; (1942) J. Amer Chem Soc, 64, 1456-1459.

[18] K. Haack, et. al; (1997)J. Catal, 36,285-288.

[19] K. Matsumura, et. al; (1997 ) J. Am. Chem. Soc.,119, 8738-8741.

[20] S. Vastag, et. al; (1979) J. Mol. Catal 5, 189-195.

[21] J. Nyhlen, et. al; (2009) Dalton Trans., 5780-5786.

[22] S. Narayanan, et. al; (1996) Faraday Trans 1, 231-235.

[23] S. Narayanan, and R. Unnikrishnan (1998) Faraday Trans 1, 94,1123-1128.

[24] W. Reith, et. al; Stud Surf. Sci. Catal. (1991) 59, 487494.

[25] S. Barman, et. al; (2006) Ind. Eng. Chem. Res., 45, 34813484.

[26] G. M. R. van Druten, and V. Ponec (2000) Appl. Catal. A General, 191,153-162.

[27] A. M. Funte, et. al; (2001) Appl Catal A, 208, 35-46.

[28] T.M. Yurieva, J. Mol. Catal. (1996) 105, 61-66.

[29] T.M. Yurieva Catalysis Today (1999) 51, 457-467.

[30] Ateeq Rahman and S B Jonnalagadda J Mol. Cat A: (2009) 299, 98-101.

[31] S. Narayanan, and R. Unnikrishnan, Stud. Surf. Sci. Catal.(1998) 113, 799-807.

[32] T.M. Yurieva Catalysis Today (1999) 51, 457-467.

[33] J. Cunningham et.al; (1990) J. Mol. Catal.57,379-384.

[34] G. M. R. van Druten, and V. Ponec (2000) Appl Catal A, 191, 153-162.
[35] L. M. Gandia, et. al; (1995) J Catal 157, 461-471.

[36] B. Sen, and M. A. Vannice (1988) J. Catal 113, 52-71.

[37] M. Okumura, et. al; Appl Catal B: Environmental, (2003 ) $41,43-52$

[38] M. K. Moghaddam, et. al; (2006) J. Mol. Catal A: 306, 11-16.

[39] L. Melo, et. al; Stud.Surf. Sci. and Catal., (1993),78, 701706.

[40] B. M. Choudary, et. al; .(2003) J. Mol. Cat206, 145-151.

[41] C. Moreau, et. al; J. Mol. Catal. (1996) 112, 133-141.

[42] E.M. Moroz, et. al; React. Kinet. Catal. Lett. (1987) 33,185-189.

[43] J. Cunningham, et. al; J. Mater. Chem., (1993) 3, 743750.

[44] T.M. Yurieva, et. al; J. Mol. Catal. (1996) 113, 455-468.

[45] J. Cunningham, et. al; Appl. Catal, (1986) 25, 129-135.

[46] I. E. Wachs and R. J. Madix, J. Catal., (1978) 53, 208227.

[47] M. Okumura, et. al; Appl Catal B: Environmental, (2003) 41, 43-52.

[48] B. J. Hussey, et. al; Tetrahedron, (1982) 38, 3769-3774.

[49] Ateeq Rahman and S. B. Jonnalagadda Catalysis letters (2008) 123, 264-268.

[50] Ateeq Rahman, et. al; Cat. Commun (2008) 9, 2417 2421.

[51] P. N. Rylander, Hydrogenation Methods, Academic Press, London, 1985, 7-35.

[52] P. Yang, et. al; Catal. Commun. (2005) 6,107-111 